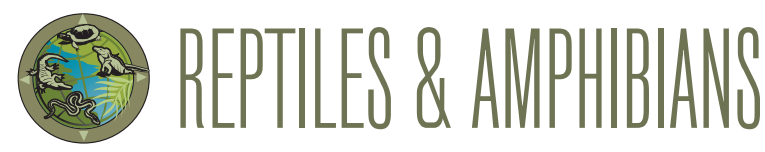

\title{
Westernmost Record of the Spotted Red Trope, Tropidophis maculatus (Squamata: Tropidophiidae), with Comments on the Tropidophis Species Assemblage from the Guanahacabibes Peninsula
}

Tomás M. Rodríguez-Cabrera ${ }^{1}$ and Roger A. Blanco Morciego ${ }^{2}$

${ }^{1}$ Instituto de Ecología y Sistemática, La Habana 11900, Cuba, and Sociedad Cubana de Zoología, Cuba (tomasmichel.rodriguez@gmail.com [corresponding author]) ${ }^{2}$ Agencia Paradiso, Artex S.A., Camagüey, Cuba (cubarog@gmail.com)

W

ith 17 endemic species, Cuba is home to the world's greatest diversity of snakes in the genus Tropidophis (Squamata: Tropidophiidae) (e.g., Hedges 2002; Domínguez et al. 2006; Díaz and Cádiz 2020; Uetz et al. 2021). Most species have limited distributions, whereas some others are widely distributed and occupy a variety of habitat types (e.g., Rodríguez Schettino et al. 2013). Such differences in geographic ranges might be related to the ecological plasticity of each species, but also to interspecific interactions and the snakes' ability to make differential use of available resources to diminish competition and coexist in the same habitats (Rodríguez-Cabrera et al. 2020a). As a general rule, Tropidophis assemblages in Cuba seem to comprise three to four species, which appears to reflect morphological and behavioral adaptations that allow the different species within each assemblage to segregate at least within a structural subniche (Rodríguez-Cabrera et al. 2020a). Consequently, three basic ecotypes (terrestrial, semi-arboreal, and generalist) exist in most habitats, although a fourth gracile and climbing variant of the semi-arboreal ecotype, always represented by the Broad-banded Trope (T. feicki), occurs in mesic forested areas with limestone cliffs in western and central Cuba (RodríguezCabrera et al. 2020a, 2020b; see also Hedges and Garrido 1992 and Díaz and Cádiz 2020 for previous references to arboreality in the genus). Syromyatnikova et al. (2021) found the first fossil evidence for the occurrence of multispecies Tropidophis assemblages at least since the Pleistocene (2.59-0.01 MYA) from cave deposits in western Cuba, where vertebrae of both the Giant Trope (T. melanurus), the almost omnipresent trope species in Cuban ecosystems, and of a second smaller unidentified species were present. The fact that regions where representatives of only some of the ecotypes have been reported does not necessarily mean that those niches are not available; instead, their representatives could

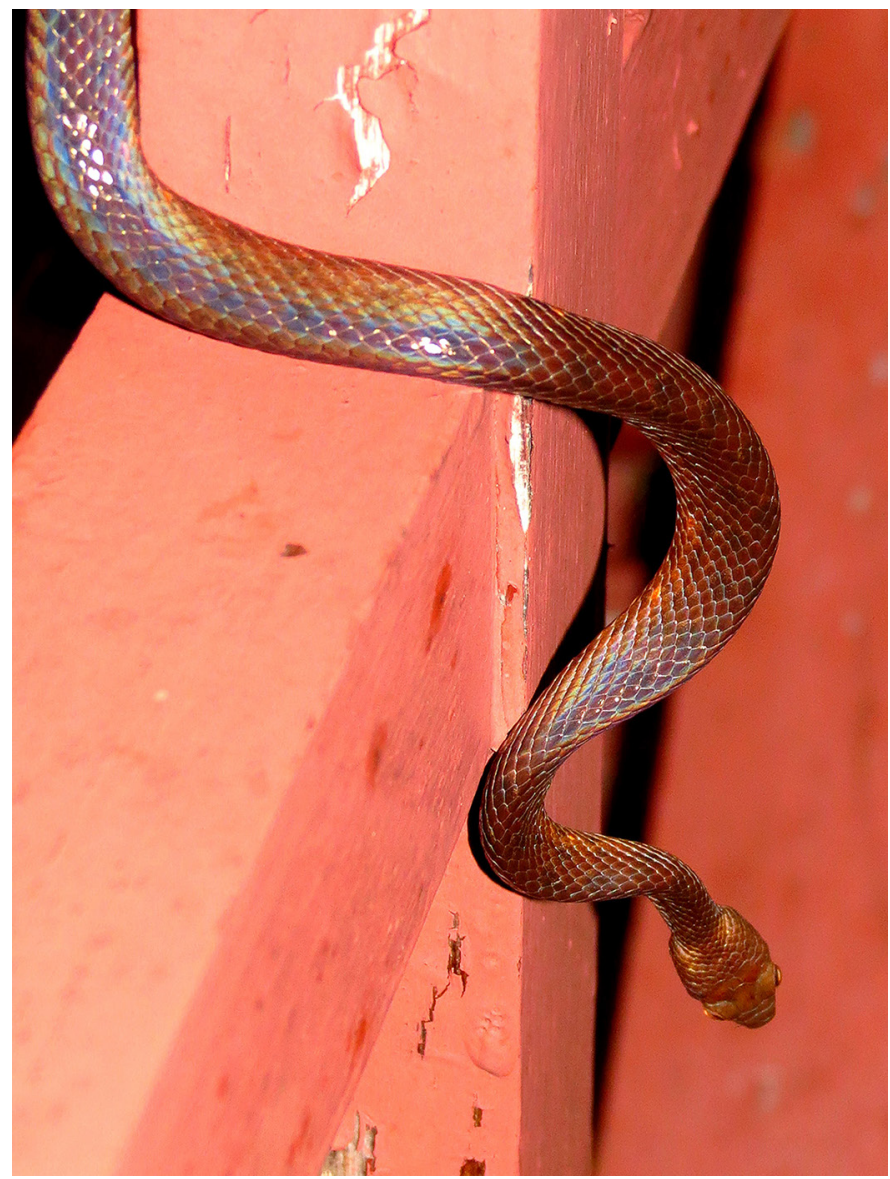

Fig. 1. An adult Spotted Red Trope (Tropidophis maculatus) when first observed at "María la Gorda" Resort, Guanahacabibes Peninsula, Pinar del Río Province, Cuba. Photograph (C) R.A. Blanco Morciego. 
be extirpated or extinct, have not yet dispersed to those areas, or have yet to be discovered.

The Guanahacabibes Peninsula, at the westernmost tip of Cuba, is one of the most important regions of the country in terms of biodiversity conservation (CNAP 2013). The herpetofauna of this peninsula has been studied for decades (e.g., Garrido and Schwartz 1968; Garrido 1980; Estrada and Novo Rodríguez 1985; Novo Rodríguez et al. 1987; Domínguez et al. 2006; Rodríguez Schettino et al. 2009). However, species of Tropidophis belonging to only two ecotypes, the terrestrial Guanahacabibes Trope (T. xanthogaster) and Spotted Brown Trope (T. pardalis) and the generalist Giant Trope, have been reported from this area (e.g., Garrido and Schwartz 1968; Domínguez et al. 2006; Rodríguez Schettino et al. 2009; Rivalta-G. et al. 2013; Rodríguez-S. et al. 2015). Herein we report for the first time the Spotted Red Trope (T. maculatus) from the Guanahacabibes Peninsula, which represents not only the westernmost occurrence of the species but also the first representative of the semi-arboreal ecotype in this region.

On 29 June 2011, one of us (RABM) observed and photographed an adult T. maculatus (ca. $350 \mathrm{~mm} \mathrm{SVL)} \mathrm{(Fig.} \mathrm{1)} \mathrm{at}$ the "María la Gorda" Resort, Cabo Corrientes, Guanahacabibes Peninsula, Sandino Municipality, Pinar del Río Province (21.8210, -84.4938; WGS 84; elev. $-1.5 \mathrm{~m}$ asl). This locality is $60 \mathrm{~km} \mathrm{SW}$ of Guane, site of the nearest reliable published record of the species (Barbour and Ramsden 1919). A photographic voucher has been deposited in the Herpetology Digital Archives of the University of Kansas (KUDA 013333). The identity of the species was confirmed by Javier Torres.

The snake was first observed at about $2000 \mathrm{~h}$ foraging approximately $1.3 \mathrm{~m}$ above the ground and $150 \mathrm{~m}$ from the shoreline on a wooden handrail in front of some rustic bungalows in the resort (Fig. 2). The principal vegetation in the area is semi-deciduous forest, whereas that in much of the resort is secondary grassland with isolated bushes, trees (coconut palms and seagrape), and ornamental plants; vegetation near the shoreline comprises mostly small groves of seagrape and sandybeach vegetation complex. The snake had the intense dark reddish ground coloration with smaller faded markings observed in some populations of $T$. maculatus, particularly those in the Guaniguanico Mountain Range, in contrast with snakes from populations farther east, which have a paler ground color with larger and more contrasting markings (Fig. 3).

Rodríguez Schettino et al. (2013) reported T. maculatus from the "San Ubaldo-Sabanalamar" Flora Reserve, located about $54 \mathrm{~km} \mathrm{NE}$ of the "María la Gorda" Resort. However, this record is based solely on the species list of an unpublished action plan for the area, which contains several other records that most certainly constitute misidentifications (Canasi Trope, T. celiae; Broad-banded Trope, T. feicki, no limestone outcrops exist in this area; Yellow-banded Trope, T. semicinctus; Mangrove Salt Marsh Snake, Nerodia clarkii; Cuban
Blue Anole, Anolis allisoni; Cuban Giant Anole, A. equestris; Slender Cliff Anole, A. lucius; North Coast Banded Geckolet, Sphaerodactylus intermedius; Canasi Frog, Eleutherodactylus blairhedgesi; and Eastern Giant Toad, Peltophryne peltocephala). Although the existence of T. maculatus in "San Ubaldo-Sabanalamar" Flora Reserve falls within the realm of possibility, additional sampling is required to corroborate its occurrence in the area and provide verification that this is the nearest record to the Guanahacabibes Peninsula, even if only by a few kilometers.
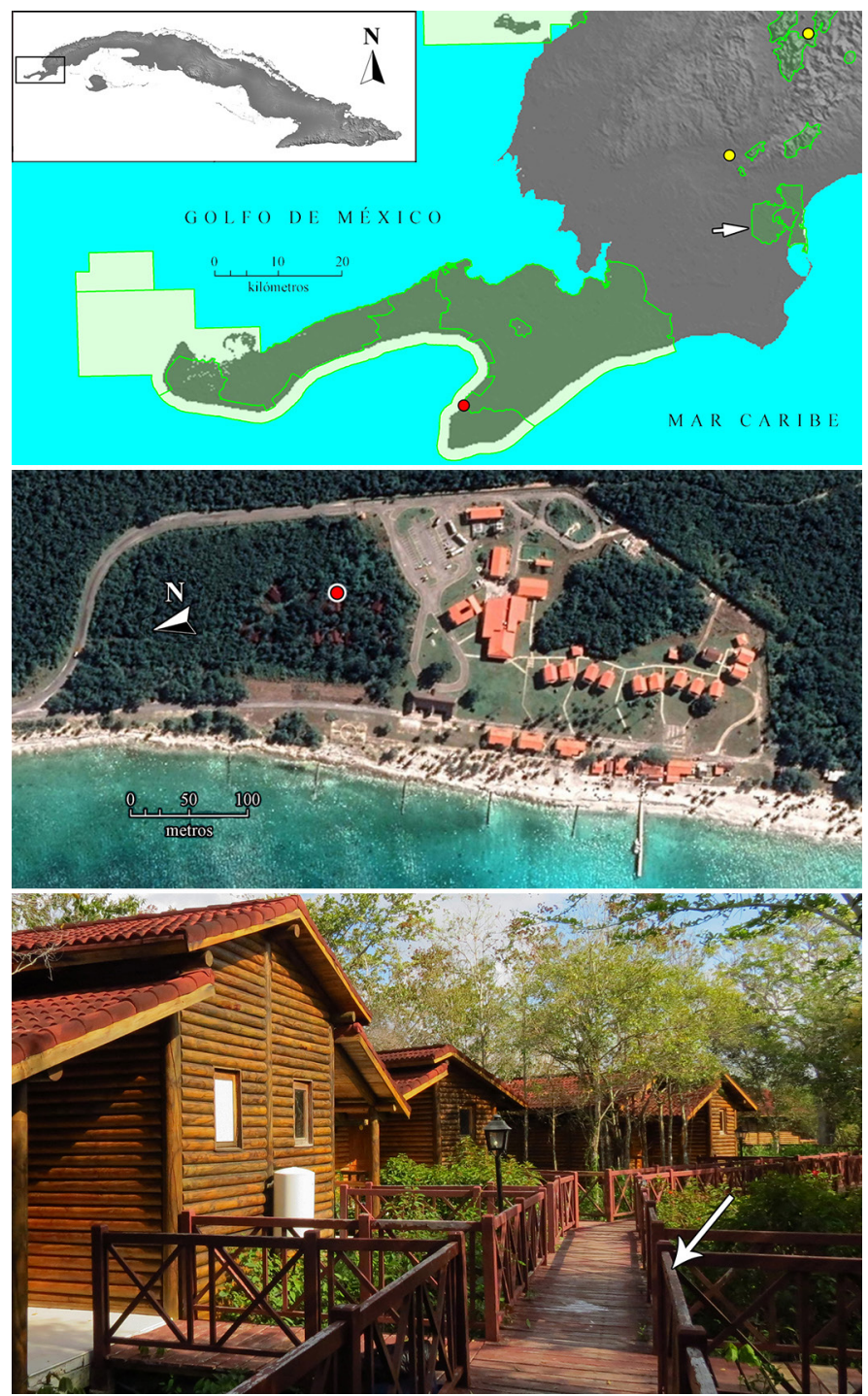

Fig. 2. Map of the Guanahacabibes Peninsula, Pinar del Río Province, Cuba, showing the location of the "María la Gorda" Resort (red dot), where we encountered a Spotted Red Trope (Tropidophis maculatus). The most proximate previous records of the species are marked by yellow dots. Green areas represent Protected Areas and the arrow indicates the "San Ubaldo-Sabanalamar" Flora Reserve, for which an unverified record of this species exists (top). A satellite image of the "María la Gorda" Resort showing the exact location where we observed the Spotted Red Trope (red dot) (center). Rustic bungalows at the resort; the arrow indicates the exact place on the wooden handrails where we encountered the Spotted Red Trope foraging at night (bottom). Photograph (c) R.A. Blanco Morciego. 


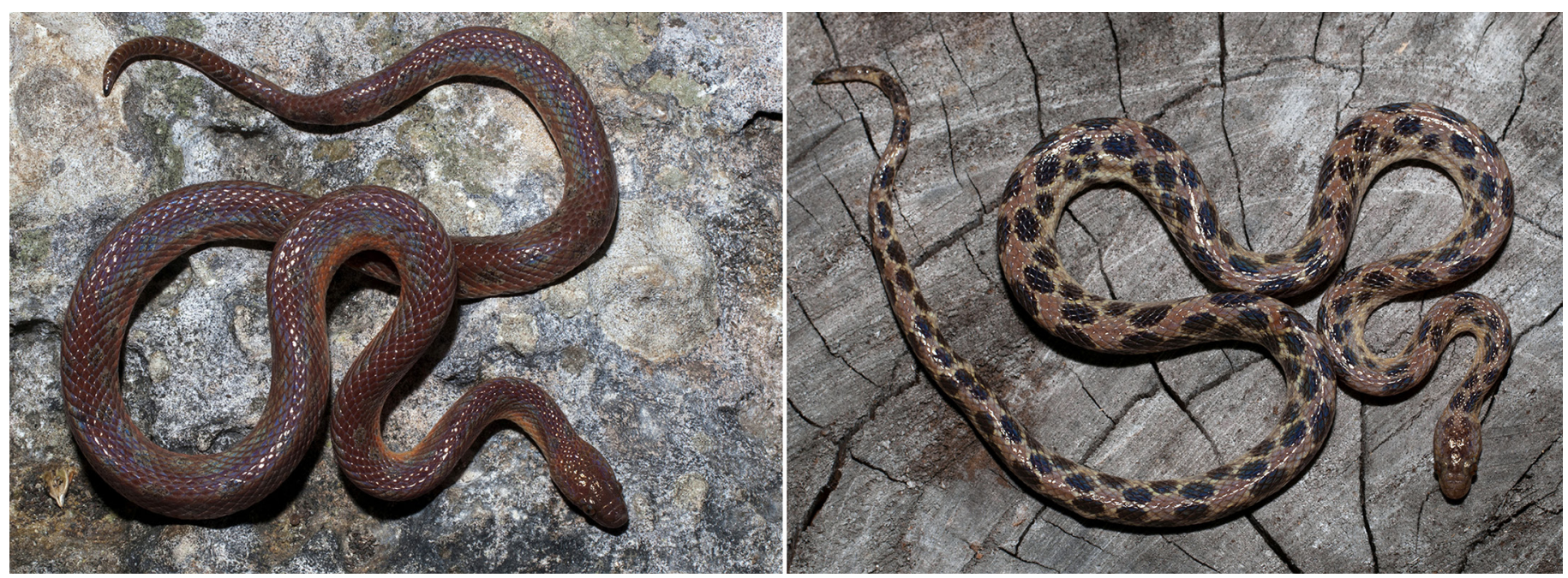

Fig. 3. Adult Spotted Red Tropes (Tropidophis maculatus) from the Santa Cruz River Canyon, San Cristobal Municipality, Artemisa Province (notice the intense dark reddish ground color with smaller faded markings, similar to the snake from the Guanahacabibes Peninsula) (left) and from Boca de Jaruco, Santa Cruz del Norte Municipality, Mayabeque Province (notice the paler ground color with larger and more contrasting markings) (right). Photographs (C) Raimundo López-Silvero.

With this new record, the Tropidophis species assemblage on the Guanahacabibes Peninsula is complete. However, a fourth species, T. feicki, might also occur on the peninsula. Tropidophis feicki occurs in much of western and central Cuba
(Rodríguez-Cabrera et al. 2020b) and is known to coexist parapatrically with $T$. maculatus (Rodríguez-Cabrera et al. 2020a). Moreover, the record closest to the Guanahacabibes Peninsula is in the Sierra de Guane, a site close to the pre-
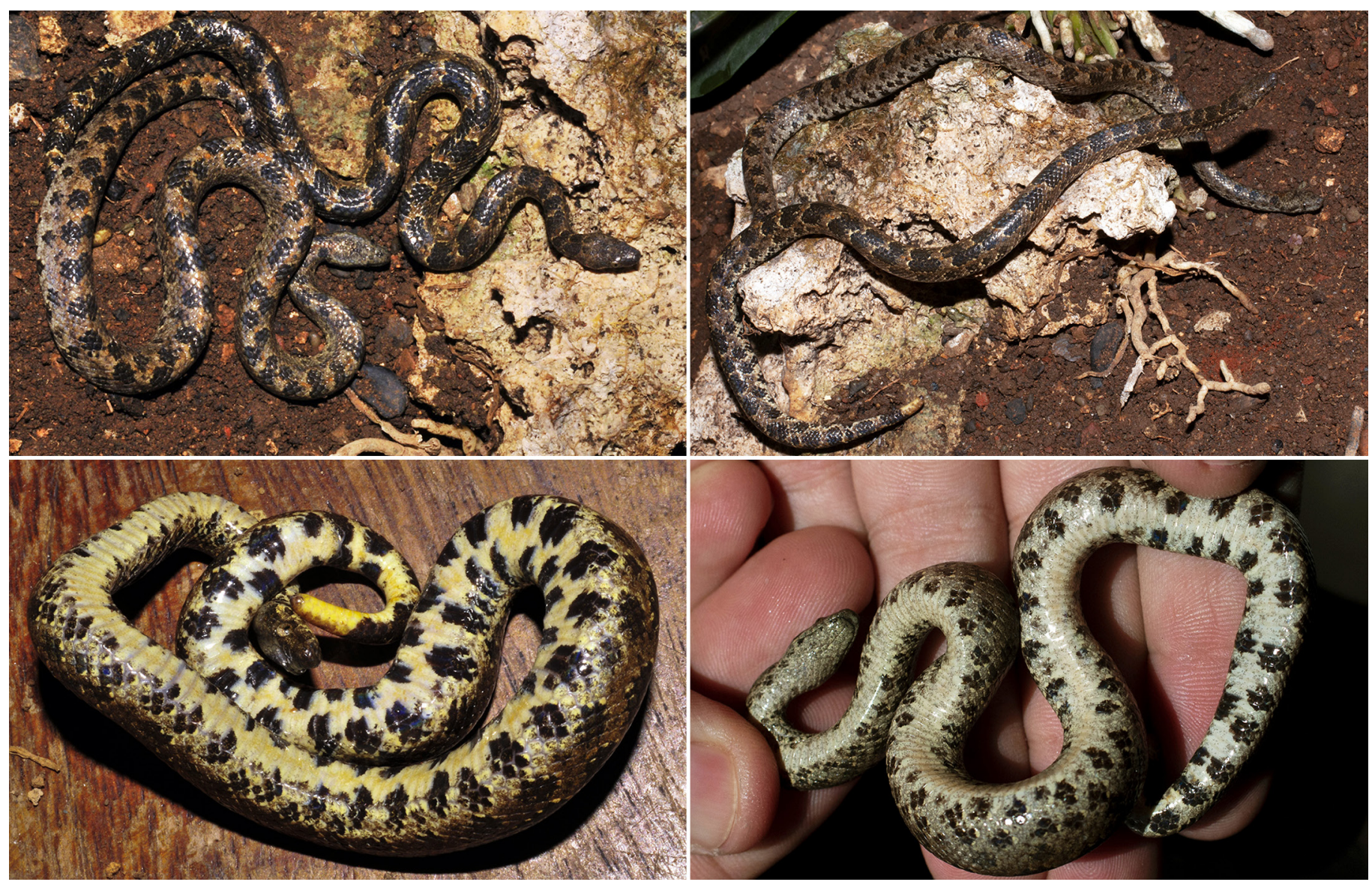

Fig. 4. Two adult Guanahacabibes Tropes (Tropidophis xanthogaster) from the same population at Las Perlas Cave on the Guanahacabibes Peninsula that vary in color and pattern. Photographs (C) Raimundo López-Silvero. 
viously documented westernmost record of $T$. maculatus (Rodríguez-Cabrera et al. 2020b).

Our observation of the individual from the "María La Gorda" Resort corroborates statements in Díaz and Cádiz (2020) and Rodríguez-Cabrera et al. (2020a, 2020c) that this species readily climbs. In this case, the snake was on a wooden handrail, similar to conspecifics observed on vegetation in more natural areas (Rodríguez-Cabrera et al. 2020a, 2020c). These actively foraging snakes feed primarily on sleeping anoles that are captured at night (Collette 1961; Rodríguez-Cabrera et al. 2020a, 2020c; Rodríguez-Cabrera and Hernández Gómez 2021). The apparent paucity of $T$. maculatus on the Guanahacabibes Peninsula could be attributable to a relatively recent dispersal of the species into the region.

Two closely related species of the terrestrial ecotype (T. pardalis and T.xanthogaster) have been reported from the Guanahacabibes Peninsula (Domínguez et al. 2006; Rodríguez Schettino et al. 2009; Rivalta-G. et al. 2013). However, due to the strong resemblance of these two species, we cannot rule out the possibility that the records of $T$. pardalis actually apply to misidentified T. xanthogaster. Individuals of the latter often vary in color and pattern (Fig. 4) and some individuals are very similar to $T$. pardalis. Tropidophis pardalis has a relatively extensive distribution and populations across the range are highly variable (Schwartz and Marsh 1960; Schwartz and Garrido 1975). Another possibility is that T. xanthogaster and T. pardalis are conspecific, and the population on the peninsula includes variants similar to both "species." In any case, the taxonomic status of snakes in the pardalis group from the Guanahacabibes Peninsula deserves further attention, which is beyond the scope of this paper. Two species of the terrestrial ecotype (T. celiae and T. pardalis) do coexist at Canasí, Mayabeque Province (RodríguezCabrera et al. 2020a), but they are not as closely related as $T$. pardalis and T. xanthogaster (see Díaz and Cádiz 2020 for a molecular phylogeny of the genus in Cuba).

\section{Acknowledgements}

We thank Javier Torres and Yaira López for useful comments that improved an early draft of this manuscript and Raimundo López-Silvero for permission to use his photographs. Javier Torres also confirmed the identity of the species and, with Melissa R. Mayhew, assisted in depositing a photographic voucher in the digital archives at the University of Kansas.

\section{Literature Cited}

Barbour, T. and C.T. Ramsden. 1919. The herpetology of Cuba. Memoirs of the Museum of Comparative Zoölogy 47: 71-213. https://doi.org/10.5962/bhl. title.49191.

CNAP (Centro Nacional de Áreas Protegidas). 2013. Plan del Sistema Nacional de Areas Protegidas 2014-2020. Ministerio de Ciencias, Tecnología y Medio Ambiente, La Habana, Cuba.

Collette, B.B. 1961. Correlations between ecology and morphology in anoline lizards from Havana, Cuba, and southern Florida. Bulletin of the Museum of Comparative Zoology 125: 137-162. https://doi.org/10.5962.BHL. PART.26162.

Díaz, L.M. and A. Cádiz. 2020. A new species of Tropidophis (Squamata: Tropidophiidae) and molecular phylogeny of the Cuban radiation of the genus. Novitates Caribaea 16: 1-9. https://doi.org/10.33800/nc.vi16.222.

Domínguez, M., L.V. Moreno, and S.B. Hedges. 2006. A new snake of the genus Tropidophis (Tropidophiidae) from the Guanahacabibes Peninsula of western Cuba. Amphibia-Reptilia 27: 427-432. https://doi. org/10.1163/156853806778190088.

Estrada, A.R. and J. Novo Rodríguez. 1985. Nueva especie de Eleutherodactylus del grupo ricordi (Anura: Leptodactylidae) del occidente de Cuba. Poeyana 303: $1-10$.

Garrido, O.H. 1980. Adiciones a la fauna de vertebrados de la Península de Guanahacabibes. Miscelánea Zoológica 10: 2-4.

Garrido, O.H. and A. Schwartz. 1968. Anfibios, reptiles y aves de la península de Guanahacabibes, Cuba. Poeyana, Serie A 53: 1-68.

Hedges, S.B. 2002. Morphological variation and the definition of species in the snake genus Tropidophis (Serpentes: Tropidophiidae). Bulletin of the Natural History Museum, London: Zoology Series 68: 83-90. https://doi.org/10.1017/ S0968047002000092.

Hedges, S.B. and O.H. Garrido. 1992. A new species of Tropidophis from Cuba (Serpentes: Tropidophiidae). Copeia 1992: 820-825. https://doi. org/10.2307/1446158.

Novo Rodríguez, J., A.R. Estrada, and L.V. Moreno. 1987. Adiciones a la fauna de anfibios de la Península de Guanahacabibes, Cuba. Miscelánea Zoológica 36: $3-4$.

Rivalta-G[onzález]., V., A. González-C., and L. Rodríguez-S[chettino]. 2013. Colección herpetológica del Instituto de Ecología y Sistemática, La Habana, Cuba. Familia Tropidophiidae, género Tropidophis. Revista Colombiana de Ciencia Animal 5: 282-300. https://doi.org/10.24188/recia.v5.n2.2013.293.

Rodríguez-Cabrera, T.M. and A. Hernández Gómez. 2021. New prey records for two snakes of the genus Tropidophis (Tropidophiidae) from urban habitats in La Habana, Cuba. Reptiles \& Amphibians 28: 512-515. https://doi. org/10.17161/randa.v23i3.15858.

Rodríguez-Cabrera, T.M., A. Fong G., and J. Torres. 2020a. New dietary records for three Cuban snakes in the genus Tropidophis (Tropidophiidae), with comments on possible niche partitioning by Cuban tropes. Reptiles \& Amphibians 27: 201-208. https://doi.org/10.17161/randa.v27i2.14177.

Rodríguez-Cabrera, T.M., J. Torres, and E. Morell Savall. 2020b. Easternmost record of the Cuban Broad-banded Trope, Tropidophis feicki (Squamata: Tropidophiidae). Caribbean Herpetology 71: 1-3. https://doi.org/10.31611/ ch.71.

Rodríguez-Cabrera, T.M., L.Y. García-Padrón, and J. Torres. 2020c. New dietary records for the Cuban Spotted Red Trope, Tropidophis maculatus (Squamata: Tropidophiidae). Caribbean Herpetology 73: 1-2. https://doi.org/10.31611/ ch.73.

Rodríguez[-]Schettino, L., V. Rivalta[-]González, E. Pérez Rodríguez, and A. Hernández Marrero. 2009. Herpetofauna de la Reserva de la Biosfera "Cuanahacabibes", provincia de Pinar del Río, Cuba. Poeyana 497: 28-43.

Rodríguez[-]Schettino, L., C.A. Mancina, and V. Rivalta[-]González. 2013. Reptiles of Cuba: Checklist and geographic distribution. Smithsonian Herpetological Information Service 144: 1-96. https://doi.org/10.5479/si.23317515.144.1.

Rodríguez-S[chettino]., L., V. Rivalta-G[onzález]., A. González-R., and R. Fernández de Arcilla-F. 2015. Presencia del género Tropidophis (Serpentes: Tropidophiidae) en el Sistema Nacional de Áreas Protegidas de Cuba. Revista Colombiana de Ciencia Animal 7: 19-24. http://dx.doi.org/10.24188/recia. v7.n1.2015.294

Schwartz, A. and R.J. Marsh. 1960. A review of the pardalis-maculatus complex of the boid genus Tropidophis of the West Indies. Bulletin of the Museum of Comparative Zoology 123: 48-89.

Schwartz, A. and O.H. Garrido. 1975. A reconsideration of some Cuban Tropidophis (Serpentes, Boidae). Proceedings of the Biological Society of Washington 9: 77-90.

Syromyatnikova, E., E. Aranda, and S. Fiol González. 2021. First insight into the diversity of snakes in the Pleistocene of Cuba. Acta Paleontologica Polonica 66: 395-407. https://doi.org/10.4202/app.00766.2020.

Uetz, P., P. Freed, R. Aguilar, and J. Hošek (eds.). 2021. The Reptile Database. $<$ http://www.reptile-database.org>. 